\title{
PENERAPAN MEDIA PEMBELAJARAN E-LEARNING BERBASIS EDMODO PADA PEMBELAJARAN DARING SAAT PANDEMI COVID-19 (DITINJAU DARI PERSEPSI SISWA)
}

\author{
Indri Oktaviani ${ }^{1}$, Ikaputera Waspada ${ }^{2}$, Neti Budiwati ${ }^{3}$ \\ 1,2,3 Universitas Pendidikan Indonesia, Bandung \\ e-mail : ${ }^{1} \underline{\text { indrioktaviani@ upi.edu }},{ }^{2}$ ikaputerawaspada@upi.edu, ${ }^{3}$ watility@gmail.com
}

Received : June 20, $2020 \quad$ Revised : June 22, $2020 \quad$ Accepted : June 24, 2020

\begin{abstract}
ABSTRAK
Penelitian ini bertujuan untuk mengetahui persepsi siswa terhadap penerapan media pembelajaran e-learning berbasis Edmodo pada pembelajaran daring saat pandemi Covid-19. Subjek penelitian ini terdiri dari 68 siswa Kelas X dan XI yang dipilih secara acak disalah satu SMK Negeri di Kota Cimahi. Instrumen penelitian yang digunakan berupa kuisioner yang terdiri dari 36 pernyataan. Teknik analisis yang digunakan oleh peneliti yaitu teknik analisis deskriptif untuk mengetahui tingkat persepsi siswa terhadap Edmodo pada pembelajaran daring. Hasil penelitian menunjukkan bahwa tingkat persepsi siswa terhadap penerapan Edmodo pada masing-masing aspek berada pada kategori tinggi, yaitu kategori pengukuran dan prestasi akademik sebesar 74\%, kategori komunikasi dan interaksi sebesar $73 \%$ dan kategori mengakes informasi sebesar $73 \%$. Sehingga dapat disimpulkan bahwa rata-rata persepsi siswa terhadap Edmodo berada pada kategori tinggi yaitu sebesar 73,3\% . Artinya menurut siswa media pembelajaran Edmodo dapat membantu mereka dalam pembelajaran daring selama pandemi Covid-19.
\end{abstract}

Kata Kunci : E-learning, Edmodo, Pembelajaran Daring, Covid-19

\section{ABSTRACT}

This study aims to know students' perceptions of the application of Instructional media with Edmodo based e-learning in online learning during the Covid-19 pandemic. The subjects of this study consisted of 68 students of Class X and XI who were randomly selected at one of the State Vocational Schools in Cimahi City. The research instrument used was a questionnaire consisting of 36 statements. The analysis technique used by researchers is descriptive analysis technique to determine the level of student perception of Edmodo in online learning. The results showed that the level of student perception of the application of Edmodo in each aspect was in the high category, namely the measurement and academic achievement category by 74\%, the communication and interaction category by $73 \%$ and the information access category by $73 \%$. So it can be concluded that the average student perception of Edmodo is in the high category that is $73.3 \%$. This means that according to students Edmodo learning media can help them in online learning during the Covid-19 pandemic.

Keywords : E-learning, Edmodo, Online Learning, Covid-19 


\section{PENDAHULUAN}

Pandemi Covid-19 telah berdampak terhadap berbagai sektor kehidupan mulai dari ekonomi, kesehatan, sosial, dan pendidikan. Pada sektor pendidikan untuk memutus penyebaran Covid-19 sejumlah negara harus menutup fasilitas pendidikan baik sekolah maupun universitas. Hal ini dikarenakan, apabalila sekolah dan universitas tidak ditutup maka sebanyak 663.339.947 pelajar berpotensi terpapar virus. Oleh sebab itu, untuk mencegah penyebaran yang lebih besar sejumlah negara harus menutup sekolah dan universitas meskpiun hal tersebut akan berdampak terhadap terganggunya proses belajar ratusan juta pelajar di dunia. (Purwanto et al., 2020).

Di Indonesia sudah lebih dari tiga bulan pemerintah harus menutup sekolah dan universitas yang berada di wilayah yang terpapar Covid-19. Penutupan sekolah di Indonesia secara langsung akan berdampak terhadap proses pembelajaran di sekolah. Guru dan siswa yang biasanya melakukan pembelajaran secara langsung di kelas, saat ini dipaksa harus berpindah ke dalam proses pembelajaran jarak jauh untuk menghindari terjadinya kerumunan sebagai langkah pencegahan penyebaran Covid-19.

Pada hakikatnya pembelajaran adalah proses untuk mengatur dan mengorganisasi seluruh lingkungan yang ada di sekitar siswa sehingga dapat menumbuhkan dan mendorong siswa melakukan proses belajar. (Pane \& Darwis Dasopang, 2017). Secara umum, terdapat dua jenis pembelajaran, yaitu pembelajaran langsung dan pembelajaran daring atau online. (Brown \& Park, 2015). Seiring dengan perkembangan teknologi informasi dan komunikasi, maka muncul sistem pembelajaran baru, yaitu pembelajaran daring. Pembelajaran daring atau pembelajaran dalam jaringan adalah pembelajaran jarak jauh yang menggunakan internet dan beberapa teknologi sebagai media yang digunakan. (Syarifudin, 2020)

Pada saat pandemi Covid-19 pembelajaran daring menjadi satu-satunya solusi agar proses pembelajaran tetap berjalan. Hal tersebut sesuai dengan arahan Menteri Pendidikan bahwa selama pandemi proses belajar mengajar dipindahkan ke rumah baik. (Menteri Pendidikan dan Kebudayaan Republik Indonesia, 2020).

Perubahan proses pembelajaran dari pembelajaran secara langsung di kelas ke dalam pembelajaran daring tentu menimbulkan berbagai macam kendala. Hal ini dikarenakan, di Indonesia baik guru ataupun siswa belum terbiasa untuk melakukan pembelajaran daring. Kelemahan utama pembelajaran daring, yaitu minimnya intensitas pertemuan antar siswa dan pengajar. (Wardani, Toenlioe, \& Wedi, 2018). Oleh sebab itu, guru sebagai harus mampu untuk mengorganisasi pembelajaran agar kualitas pembelajaran daring dapat ditingkatkan. Pada pembelajaran daring guru harus mampu menyajikan pembelajaran dengan menggunakan media yang tepat agar proses belajar yang dialami siswa dapat berhasil. (Jamal, 
2020). Jenis media pembelajaran yang tepat untuk digunakan dalam pembelajaran daring adalah media pembelajaran berbasis teknologi atau yang dikenal dengan e-learning. (Nair, 2017). Salah satu jenis media pembelajaran e-learning yang biasanya digunakan untuk pembelajaran daring, yaitu Edmodo. (Sugiyanto \& Setiawan, 2018).

Edmodo adalah sebuah media pembelajaran berbasis website gratis yang membantu guru dalam proses pembelajaran. Saat ini, Edmodo dapat digunakan pada berbagai perangkat komunikasi seperti smartphone, tablet, dan perangkat lainnya. (Hutter, 2012). Edmodo digunakan untuk membantu proses pembelajaran di antara guru dan siswa tanpa terhalang oleh ruang dan waktu. Selain itu, Edmodo juga berguna untuk (1) mendorong untuk pembelajaran secara mandiri, (2) meningkatkan keterampilan pemecahan masalah, (3) meningkatkan motivasi belajar siswa dan (4) membantu siswa meningkatkan keterampilan berpikir. (Charoenwet \& Christensen, 2016).

Pada pembelajaran daring berbagai macam fitur Edmodo dapat digunakan untuk menunjang keberhasilan pembelajaran. Adapun fitur-fitur yang disediakan oleh Edmodo, yaitu (1) Create a group berfungsi untuk membuat grup untuk anggota. (2) Notes berfungsi untuk mengirim pengumuman, komentar, peringatan, serta berbagi file media dan gambar, dengan seluruh anggota grup. (3) Assignments berfungsi untuk mengupload tugas dan membuat jadwal tugas. (4) Quizzes berfungsi untuk membuat kuis dalam berbagai format, seperti pilihan ganda, mencocokkan, benar dan salah, dan uraian. (5) Check progress/badges berfungsi untuk melihat kemajuan siswa secara individu atau keseluruhan. (6) Polls berfungsi untuk melakukan jejak pendapat atau pollings. (7) Library berfungsi untuk penyimpanan file dalam cloud. (8) Calendar berfungsi untuk menandai tanggal-tanggal penting. (9) Support team merupakan fasilitas yang diberikan oleh Edmodo untuk memberikan bantuan secara online dan sangat cepat dalam menanggapi pertanyaan guru di seluruh dunia. (10) Annual conferences merupakan fitur dari Edmodo untuk menyelenggarakan konferensi tahunan untuk menyatukan seluruh pengguna di seluruh dunia. (Sugiyanto \& Setiawan, 2018).

Selain memiliki fitur-fitur yang menunjang pembelajaran, Edmodo juga memiliki kelemahan. Terdapat dua hal utama yang menjadi kelemahan Edmodo, yaitu (1) Edmodo tidak dapat digunakan jika tidak terhubung dengan Internet. Oleh sebab itu, guru dan siswa harus memastikan ketersdiaan internet dalam pembelajaran. (2) Edmodo hanya dapat dijalankan oleh perangkat yang mendukung seperti komputer, laptop, atau smarthphone. Oleh karena itu, guru harus mematikan apakah siswa memiliki perangkat yang menunjang untuk menggunakan Edmodo. (Haq, 2018) 
Peneliti mencoba untuk menganalisis tentang penerapan media pembelajaran e-learning berbasis Edmodo. Perbedaan penelitian ini dengan penelitian sebelumnya terletak pada subjek penelitian, lokasi penelitian, waktu penelitian, dan masalah penelitian. Berdasarkan latar belakang dan penelitian sebelumnya, maka peneliti tertarik untuk mengkaji persepsi siswa tentang penerapan media pembelajaran e-learning berbasis Edmodo pada pembelajaran daring saat pandemi Covid-19. Oleh karena itu, perlu dilakukan studi deskriptif tentang penerapan media pembelajaran Edmodo pada pembelajaran daring saat pandemi Covid-19 yang dilihat dari persepsi siswa.

\section{METODE}

Metode yang digunakan dalam penelitian ini adalah metode survey deskriptif untuk menganalisis persepsi siswa tentang penerapan media pembelajaran e-learning berbasis Edmodo pada pembelajaran daring saat pandemi Covid-19. Populasi dari penelitian ini adalah seluruh siswa Kelas X dan XI di salah satu SMK di Kota Cimahi yang berjumlah 214 siswa. Gambaran umum populasi berdasarkan kelas, yaitu Kelas X berjumlah 108 siswa yang terdiri dari 9 orang siswa laki-laki dan 99 orang siswa perempuan. Kelas XI berjumlah 106 siswa yang terdiri dari dari 9 orang siswa laki-laki dan 97 orang siswa perempuan.

Penentuan jumlah responden dilakukan dengan menggunakan teknik pengambilan sample menggunakan rumus Slovin dengan batasan kesalahan $10 \%$ sehingga diperoleh sample sebanyak 68 siswa yang dipilih secara acak. Instrumen yang digunakan oleh peneliti adalah kuisioner untuk mengetahui persepsi siswa tentang penerapan media pembelajaran $e$ learning berbasis Edmodo pada pembelajaran daring saat pandemi Covid-19. Kuisioner yang diberikan terdiri dari 36 pernyataan dengan skala likert 1-5 yang diadopsi dari Al-Said (2015). Masing-masing pernyataan memiliki skor dari jawaban positif sampai negatif sebagai berikut : sangat setuju (5), setuju (4), ragu-ragu (3), tidak setuju (2) dan sangat tidak setuju (1). Teknik analisis data yang digunakan adalah teknik analisis data deskriptif dengan bantuan SPSS untuk mengetahui persepsi siswa terhadap penerapan media pembelajaran $e$ learning berbasis Edmodo.

\section{HASIL DAN PEMBAHASAN}

Data yang sudah diperoleh dianalisis secara deskriptif dengan bantuan SPSS. Data yang telah diolah digunakan untuk menggambarkan bagaimana presepsi siswa terhadap media pembelajaran e-learning berbasis Edmodo pada pembelajaran daring. Gambaran tersebut dianalisis dari tiga aspek, yaitu (1) pengukuran dan prestasi akademik, (2) komunikasi dan interaksi, (3) serta dalam hal mengakes informasi. 
Tabel. 1 Pesersepsi Siswa Terhadap Edmodo Dilihat dari Aspek Pengukuran dan Prestasi Akademik

\begin{tabular}{|c|c|c|c|}
\hline No. & Pernyataan & $\mathrm{M}$ & $\mathrm{SD}$ \\
\hline 1 & $\begin{array}{l}\text { Saya berharap Edmodo } \\
\text { dapat digunakan untuk } \\
\text { meningkatkan } \\
\text { motivasi belajar. }\end{array}$ & 3,78 & 0,62 \\
\hline 2 & $\begin{array}{l}\text { Saya pikir bahwa } \\
\text { penggunaan Edmodo } \\
\text { dalam pembelajaran } \\
\text { membantu dalam } \\
\text { mendapatkan respon } \\
\text { dengan cepat. }\end{array}$ & 3,87 & 0,57 \\
\hline 3 & $\begin{array}{l}\text { Saya merasa bahwa } \\
\text { belajar menggunakan } \\
\text { Edmodo membantu } \\
\text { meningkatkan prestasi } \\
\text { akademik. }\end{array}$ & 3,59 & 0,65 \\
\hline 4 & $\begin{array}{l}\text { Saya merasa bahwa } \\
\text { penggunaan Edmodo } \\
\text { memudahkan proses } \\
\text { pembelajaran online. }\end{array}$ & 3,96 & 0,72 \\
\hline 5 & $\begin{array}{l}\text { Saya percaya bahwa } \\
\text { prestasi berlajar saya } \\
\text { mungkin meningkat } \\
\text { setelah menggunakan } \\
\text { Edmodo }\end{array}$ & 3,22 & 0,67 \\
\hline 6 & $\begin{array}{l}\text { Saya setuju untuk } \\
\text { melakukan kuis/ujian } \\
\text { melalui Edmodo. }\end{array}$ & 4,00 & 0,46 \\
\hline 7 & $\begin{array}{l}\text { Saya berpikir bahwa } \\
\text { menggunakan Edmodo } \\
\text { mengarah untuk } \\
\text { memperkaya tugas } \\
\text { pembelajaran online }\end{array}$ & 3,60 & 0,65 \\
\hline 8 & $\begin{array}{l}\text { Saya pikir bahwa } \\
\text { menggunakan Edmodo } \\
\text { dapat meningkatkan } \\
\text { kemandirian belajar di } \\
\text { antara siswa. }\end{array}$ & 3,94 & 0,69 \\
\hline 9 & $\begin{array}{l}\text { Saya pikir bahwa } \\
\text { menggunkan Edmodo } \\
\text { membantu dalam } \\
\text { mengevaluasi } \\
\text { pembelajaran secara } \\
\text { berkelanjutan. }\end{array}$ & 3,84 & 0,64 \\
\hline 10 & $\begin{array}{l}\text { Saya pikir bahwa } \\
\text { penggunaan Edmodo } \\
\text { membantu dalam } \\
\text { mengembangkan } \\
\text { keterampilan berpikir }\end{array}$ & 3,75 & 0,70 \\
\hline
\end{tabular}




\begin{tabular}{|c|c|c|c|}
\hline & kritis. & & \\
\hline 11 & $\begin{array}{l}\text { Edmodo dapat } \\
\text { digunakan untuk } \\
\text { meningkatkan } \\
\text { pembelajaran tata } \\
\text { muka di kelas. }\end{array}$ & 3,69 & 0,60 \\
\hline 12 & $\begin{array}{l}\text { Edmodo tidak } \\
\text { menghasilkan } \\
\text { lingkungan belajar } \\
\text { yang efektif. }\end{array}$ & 2,91 & 0,75 \\
\hline 13 & $\begin{array}{l}\text { Edmodo memfasilitasi } \\
\text { pembelajaran sekolah }\end{array}$ & 4,04 & 0,61 \\
\hline
\end{tabular}

Berdasarkan hasil pengolahan data pada Tabel. 1 perolehan skor paling tinggi terdapat pada pernyataan bahwa "Edmodo memfasilitasi pembelajaran sekolah". Hal tersebut ditunjukkan dengan lebih dari $80 \%(\mathrm{M}=4,04$ dan $\mathrm{SD}=0,61)$ setuju dengan pernyataan tersebut. Perolehan skor tertinggi ke dua, yaitu terdapat pada pernyataan "Saya setuju untuk melakukan kuis/ujian melalui Edmodo" dengan perolehan skor mean $=4,00$ dan $\mathrm{SD}=0,46$. Kemudian, perolehan skor tertinggi ketiga terdapat pada pernyataan "Saya merasa bahwa penggunaan Edmodo memudahkan proses pembelajaran online" dengan perolehan skor mean $=3,96$ dan $\mathrm{SD}=0,72(79 \%)$. Lebih dari $60 \%$ setuju dengan pernyataan "Saya percaya bahwa prestasi berlajar saya mungkin meningkat setelah menggunakan Edmodo" (64\%). Apabila dilihat kembali, sebagian besar item pernyataan mendapatkan perolehan skor mean antara 3,00 sampai 4,04.

Hanya ada satu pernyataan yang mendapatkan skor mean dibawah 3,00 yaitu pernyataan No. 12 dengan skor mean $=2,91$ dan $\mathrm{SD}=0,75$. Artinya sebesar $52 \%$ setuju bahwa Edmodo cukup menciptakan lingkungan belajar yang efektif bagi siswa selama pembelajaran daring. Rata-rata perolehan skor untuk aspek pengukuran dan prestasi akademik, yaitu mean $=253$ dan $\mathrm{SD}=3,71$.

Tabel. 2 Pesersepsi Siswa Terhadap Edmodo Dilihat dari Aspek Komunikasi dan Interaksi

\begin{tabular}{clcc}
\hline No & \multicolumn{1}{c}{ Pernyataan } & M & SD \\
\hline 14 & $\begin{array}{l}\text { Edmodo memfasilitas } \\
\text { untuk belajar dimana saja } \\
\text { dan kapan saja. }\end{array}$ & 4,32 & 0,63 \\
\hline $\begin{array}{l}\text { Saya percaya bahwa } \\
\text { Edmodo mendorong } \\
\text { interaksi dan partisipasi } \\
\text { siswa ketika pembelajaran } \\
\text { online. }\end{array}$ & 3,97 & 0,65 \\
16 & $\begin{array}{l}\text { Saya merasa Edmodo } \\
\text { meningkatkan kerja sama }\end{array}$ & 3,51 & 0,68 \\
\hline
\end{tabular}


di antara para siswa

Saya pikir Edmodo tidak

dapat digunakan untuk

17 memfasilitasi komunikasi

$3,04 \quad 0,90$

antara siswa dan satu sama

lain.

Saya pikir belajar melalui

18 Edmodo memfasilitasi

interaksi dan komunikasi

di antara guru dan siswa.

Saya pikir belajar

19

menggunakan Edmodo

menguatkan hubungan

sosial antar siswa

Tabel 2 menunjukkan skala persepsi siswa terhadap Edmodo untuk aspek komunikasi dan interaksi dengan perolehan rata-rata skor untuk seluruh pernyataan, yaitu mean $=250$ dan $\mathrm{SD}=3,67$. Perolehan skor mean berada pada rentang 3,04 sampai 4,32. Berdasarkan Tabel. 2 terlihat bahwa lebih dari 70\% $(\mathrm{M}=3,97$ dan $\mathrm{SD}=0,65)$ setuju dengan pernyataan "Saya percaya bahwa Edmodo mendorong interaksi dan partisipasi siswa ketika pembelajaran online". Namun pernyataan tersebut bukanlah pernyataan yang memiliki skor tertinggi. Hal tersebut menunjukkan bahwa $86 \%$ setuju bahwa melalui Edmodo siswa dapat belajar dimana saja dan kapan saja tanpa terhalang oleh ruang dan waktu. Pernyataan No. 18 dan No. 16 secara berurutan mendapatkan respon sebesar $76 \%$ dan $70 \%$. Lebih dari $60 \%$ siswa setuju terhadap pernyataan No. 19 (68\%) dan pernyataan No. 17 (61\%).

Tabel. 3 Pesersepsi Siswa Terhadap Edmodo Dilihat dari Aspek Mengakes Informasi

\begin{tabular}{clcc}
\hline No. & \multicolumn{1}{c}{ Pernyataan } & M & 0,51 \\
\hline 20 & $\begin{array}{l}\text { Melalui Edmodo saya dapat } \\
\text { mengakses lebih cepat bahan } \\
\text { ajar yang saya butuhkan }\end{array}$ & 3,78 & 0,86 \\
21 & $\begin{array}{l}\text { Belajar di Edmodo lebih mudah } \\
\text { daripada belajar tatap muka di } \\
\text { kelas. }\end{array}$ & 2,79 & 0,56 \\
22 & $\begin{array}{l}\text { Saya merasa nyaman saat } \\
\text { belajar melalui Edmodo }\end{array}$ & 3,53 & 0,50 \\
23 & $\begin{array}{l}\text { Menggunakan Edmodo dapat } \\
\text { menghemat waktu dan tenaga } \\
\text { untuk mendapatkan informasi. }\end{array}$ & 3,93 & 0,43 \\
24 & $\begin{array}{l}\text { Mengakses informasi } \\
\text { pembelajaran menjadi lebih } \\
\text { mudah ketika menggunakan }\end{array}$ & 3,93 & 0,53 \\
Edmodo. & $\begin{array}{l}\text { Saya ingin meningkatkan } \\
\text { keterampilan dalam } \\
\text { menggunakan Edmodo. }\end{array}$ & 3,85 & 0,40 \\
\hline 26 & Saya merasa Edmodo & 3,96 & \\
\hline
\end{tabular}




\begin{tabular}{|c|c|c|c|}
\hline & $\begin{array}{l}\text { membantu keterampilan saya } \\
\text { dalam mencari informasi. }\end{array}$ & & \\
\hline 27 & $\begin{array}{l}\text { Saya tertarik untuk berdiskusi } \\
\text { tentang Edmodo }\end{array}$ & 3,51 & 0,50 \\
\hline 28 & $\begin{array}{l}\text { Dengan Edmodo saya dapat } \\
\text { mengakses materi pembelajaran } \\
\text { kapan saja dan di mana saja. }\end{array}$ & 4,19 & 0,58 \\
\hline 29 & $\begin{array}{l}\text { Saya percaya bahwa Edmodo } \\
\text { adalah aspek dari kemanjuan } \\
\text { teknologi saat ini. }\end{array}$ & 4,18 & 0,57 \\
\hline 30 & $\begin{array}{l}\text { Saya tidak punya keinginan } \\
\text { untuk berpartisipasi dalam } \\
\text { diskusi yang berkaitan dengan } \\
\text { Edmodo }\end{array}$ & 2,49 & 0,74 \\
\hline 31 & $\begin{array}{l}\text { Saya mencoba mencari tahu } \\
\text { informasi lebih lanjut tentang } \\
\text { penggunaan Edmodo }\end{array}$ & 3,65 & 0,64 \\
\hline 32 & $\begin{array}{l}\text { Saya ingin menghadiri pelatihan } \\
\text { tentang penggunaan Edmodo. }\end{array}$ & 3,25 & 0,63 \\
\hline 33 & $\begin{array}{l}\text { Hasil pembelajaran saya yang } \\
\text { terbaik adalah saat saya tidak } \\
\text { belajar melalui Edmodo. }\end{array}$ & 3,21 & 0,78 \\
\hline 34 & $\begin{array}{l}\text { Saya menyukai Edmodo karena } \\
\text { memungkinkan saya untuk } \\
\text { belajar di waktu yang tepat }\end{array}$ & 3,84 & 0,56 \\
\hline 35 & $\begin{array}{l}\text { Saya lebih suka membaca } \\
\text { materi pembelajaran saya dalam } \\
\text { bentuk kertas daripada } \\
\text { membacanya melalui Edmodo. }\end{array}$ & 3,74 & 0,82 \\
\hline 36 & $\begin{array}{l}\text { Saya merasa bahwa } \\
\text { menggunakan Edmodo } \\
\text { menghemat waktu dan upaya } \\
\text { saya untuk mendapatkan materi } \\
\text { pembelajaran. }\end{array}$ & 3,87 & 0,54 \\
\hline
\end{tabular}

Tabel. 3 bersisi informasi dengan skala persepsi siswa terhadap Edmodo untuk aspek mengakses informasi. Pernyataan No. 28 mendapatkan perolehan skor tertinggi, yaitu skor mean $=4,19$ dan $\mathrm{SD}=0,58$. Artinya $84 \%$ setuju bahwa dengan Edmodo siswa dapat mengakses materi pembelajaran kapan saja dan di mana saja. Skor tertinggi kedua terdapat pada pernyataan No. 29 yaitu "Saya percaya bahwa Edmodo adalah aspek dari kemanjuan teknologi saat ini" dengan skor mean $=4,18$ dan $\mathrm{SD}=0,57$ (83\%). Skor tertinggi ketiga terdapat pada pernyataan "Saya merasa Edmodo membantu keterampilan saya dalam mencari informasi” dengan skor mean $=3,96$ dan $\mathrm{SD}=0,40$ (79\%). Lebih dari $60 \%$ siswa setuju dengan pernyataan No. $32(65 \%)$ dan No. 33 (64\%). Sebagian besar pernyataan berada pada rentang skor mean 3.00 sampai 4,19. Hanya ada dua pernyataan yang memiliki skor mean di bawah 3.00, yaitu pernyataan No. $21(\mathrm{M}=2,79$ dan $\mathrm{SD}=0,86)$ dan No. $30(\mathrm{M}=2,49$ dan SD 
$=0,74)$. Pada aspek mengakses informasi rata-rata perolehan skor untuk seluruh pernyataan, yaitu mean $=247$ dan $\mathrm{SD}=3,63$.

Tabel 4. Kategori Persepsi Siswa

\begin{tabular}{cc}
\hline Persentase $(\%)$ & Kategori \\
\hline $81-100$ & Sangat Tinggi \\
$61-80$ & Tinggi \\
$41-60$ & Rendah \\
$<=40$ & Sangat Rendah \\
\hline
\end{tabular}

Berdasarkan rata-rata persentase dari tiap aspek diperoleh keterangan sebagai berikut : (1) Persepsi siswa terhadap Edomodo untuk aspek pengukuran dan prestasi akademik berada dalam kategori tinggi (74\%). (2) Persepsi siswa terhadap Edomodo untuk aspek komunikasi dan interaksi berada dalam kategori tinggi (73\%). (3) Persepsi siswa terhadap Edomodo untuk aspek mengakes informasi berada dalam kategori tinggi (73\%) Sehingga rata-rata persentase siswa untuk ketiga aspek tersebut adalah tinggi (73,3\%). Hal tersebut didukung oleh Hanh (2017) menyatakan bahwa Edmodo merupakan sebuah media pembelajaran yang baik bagi guru dan siswa. Hal tersebut dikarenakan, Edmodo membantu siswa untuk meningkatkan pengetahuan mereka dan memotivasi meraka dalam pembelajaran.

\section{KESIMPULAN}

Hasil penelitian menunjukkan bahwa mayoritas siswa memiliki persepsi yang tinggi terhadap penggunaan media pembelajaran edmodo pada pembelajaran daring. Oleh karena itu, peneliti merekomendasikan kepada guru untuk menjadikan edmodo sebagai alternatif media pembelajaran pada pembelajaran daring selama pandemi Covid-19. Sedangkan saran peneliti bagi peneliti selanjutnya, yaitu agar dapat melakukan penelitian terhadap variabelvariabel yang dipengaruhi oleh media pembelajaran edmodo, seperti hasil belajar, motivasi belajar, minat belajar, dll. yang tidak diteliti dalam penelitian ini.

\section{DAFTAR PUSTAKA}

Al-Kathiri, F. (2015). Beyond the Classroom Walls: Edmodo in Saudi Secondary School EFL Instruction, Attitudes and Challenges. English Language Teaching, 8(1), 189-204.

Al-Said, K. M. (2015). Students' perceptions of edmodo and mobile learning and their real barriers towards them. Turkish Online Journal of Educational Technology, 14(2), 167180 . 
Bicen, H. (2015). The Role of Social Learning Networks in Mobile Assisted Language Learning: Edmodo as a Case Study. J. UCS, 21(10), 1297-1306.

Brown, J. C., \& Park, H.-S. (2015). Comparing student research competencies in online and traditional face-to-face learning environments. The Online Journal of Distance Education and e-Learning, 3(1), 1-7.

Charoenwet, S., \& Christensen, A. (2016). The effect of Edmodo learning network on students' perception, self-regulated learning behaviors and learning performance. Proceedings of The 10th International Multi-Conference on Society, Cybernetics and Informatics (IMSCI 2016), 297-300.

COVID-19, G. T. (2020). Infografis COVID-19 (3 Juni 2020). Diambil dari Gugus Tugas Percepatan Penanganan COVID-19 website: https://covid19.go.id/p/berita/infografiscovid-19-3-juni-2020

Eryilmaz, M. (2015). The Effectiveness Of Blended Learning Environments. Contemporary Issues in Education Research (CIER), 8(4), 251-256. https://doi.org/10.19030/cier.v8i4.9433

Hanh, T. T. (2017). Exploring Students 'Perceptions on The Use of Edmodo As A Supplementary Tool In Learning. 174(14), 123-128. https://doi.org/10.1186/14726920-7-5

Haq, A. A. (2018). Blended Learning Design For English Teaching: An Empirical Case Of Edmodo In Efl Class. The 2nd National Telcecon (Teaching, Linguistics, Culture, And Education Conference) "Pendidikan di Era 4.0," 1-6.

Hutter, C. (2012). Edmodo. San Mateo, CA: Edmodo.

Jamal, S. (2020). Analisis Kesiapan Pembelajaran E-Learning Saat Pandemi Covid-19 Di SMK Negeri 1 Tambelangan. 8, 16-22.

Menteri Pendidikan dan Kebudayaan Republik Indonesia. (2020). Surat Edaran Nomor 4 Tahun 2020 Tentang Pelaksanaan Kebijakan Pendidikan Dalam Masa Darurat Penyebaran Coronavirus Disease (Covid- 19) (hal. 4-6). hal. 4-6. Jakarta: Kementerian Pendidikan dan Kebudayaan.

Nair, R. (2017). Enforcement of Online Learning: A Sustainable Pulling Mechanism in Attracting Students in Private Institutions. Medwell Journals, Vol. 12, hal. 1510-1515.

Pane, A., \& Darwis Dasopang, M. (2017). Belajar Dan Pembelajaran. FITRAH:Jurnal Kajian Ilmu-ilmu Keislaman, 3(2), 333. https://doi.org/10.24952/fitrah.v3i2.945

Purwanto, A., Pramono, R., Asbari, M., Santoso, P. B., Wijayanti, L. M., Choi, C. H., \& Putri, R. S. (2020). Studi Eksploratif Dampak Pandemi COVID-19 Terhadap Proses Pembelajaran Online di Sekolah Dasar. EduPsyCouns: Journal of Education, 
Psychology and Counseling, 2(1), 1-12. Diambil dari https://ummaspul.ejournal.id/Edupsycouns/article/view/397

Sugiyanto, \& Setiawan, A. (2018). Comparison of mobile learning applications in classroom learning in vocational education technology students based on usability. Materials Science and Engineering, 1-7. https://doi.org/10.1088/1757-899X/434/1/012251

Syarifudin, A. S. (2020). Impelementasi Pembelajaran Daring Untuk Meningkatkan Mutu Pendidikan Sebagai Dampak Diterapkannya Social Distancing. Jurnal Pendidikan Bahasa dan Sastra Indonesia Metalingua, 5(1), 31-34. https://oi.org/10.21107/metalingua.v5i1.7072

Wardani, D. N., Toenlioe, A. J. E., \& Wedi, A. (2018). Daya Tarik Pembelajaran Di Era 21 Dengan Blended Learning. Jurnal Kajian Teknologi Pendidikan (JKTP), 1(1), 13-18.

World Health Organization. (2020a). Coronavirus disease (COVID-19) outbreak situation. Diambil dari World Health Organization (WHO) website: https://www. who.int/emergencies/d iseases/novel-coronavirus-2019

World Health Organization. (2020b). QA for public. Diambil dari World Health Organization (WHO) website: https://www. who.int/indonesia/news/novel-coronavirus/qa-for-public 